\title{
Do Political Attitudes and Religiosity Share a Genetic Path?
}

\author{
Amanda Friesen \\ Department of Political Science \\ Faculty Research Fellow, Center for the Study of Religion and American Culture \\ Indiana University-Purdue University Indianapolis \\ CA504J, 425 University Blvd, Indianapolis, IN 46202 \\ amfriese@iupui.edu
}

\author{
Aleksander Ksiazkiewicz \\ Department of Political Science \\ Rice University \\ aleksks@rice.edu
}

\begin{abstract}
Social scientists have long recognized and sought to explain a connection between religious and political beliefs. Our research challenges the prevalent view that religion and politics constitute separate but related belief sets with a conceptual model that suggests the correlation between the two may be partially explained by an underlying psychological construct reflecting first principle beliefs on social organization. Moreover, we also push this challenge further by considering whether part of the relationship between political and religious beliefs is the result of shared genetic influences, which would suggest that a shared biological predisposition, or set of biological predispositions, underlies these attitudes. Using a classic twin design on a sample of American adults, we demonstrate that certain religious, political, and first principle beliefs can be explained by genetic and unique environmental components, and that the correlation between these three trait structures is primarily due to a common genetic path. As predicted, this relationship is found to hold for social ideology, but not for economic ideology. These findings provide evidence that the overlap between the religious and the political in the American context may in part be due to underlying principles regarding how to understand and organize society and that these principles may be adopted to satisfy biologically-influenced psychological needs.
\end{abstract}

Key words: Behavior genetics; religion and politics; twin study; ideology

The data employed in this project is publicly available and collected with the financial support of the National Science Foundation in the form of SES-0721378, PI: John R. Hibbing; Co-PIs: John R. Alford, Lindon J. Eaves, Carolyn L. Funk, Peter K. Hatemi, and Kevin B. Smith, and with the cooperation of the Minnesota Twin Registry at the University of Minnesota, Robert Krueger and Matthew McGue, Directors.

This is the author's manuscript of the article published in final edited form as:

Friesen, A., \& Ksiazkiewicz, A. (2014). Do Political Attitudes and Religiosity Share a Genetic Path? Political Behavior, 1-28. Available from: http://dx.doi.org/10.1007/s11109-014-9291-3 
Social scientists have long recognized and sought to explain a connection between religious and political beliefs. Alignment theories, for example, seek to explain why religious groups associate with American political parties (Layman 2001; Smidt, den Dulk, Froehle, Penning, Monsma and Koopman 2010), and individual-level studies of believing, behaving, and belonging suggest levels of religious commitment and orthodoxy co-vary with individual differences in political beliefs (Smidt, Kellstedt and Guth 2009; Wald and Calhoun-Brown 2007). Yet, such frameworks do not provide comprehensive answers to questions of why religious and political orientations intersect. At least in part, this is because existing political science frameworks tend to treat political and religious attitudes as independent concepts and frequently ignore the common origins of these belief systems. The notion that these belief systems may not be independent, that they may be the product of common underlying environmental and, especially, biological forces has only been recently tested and integrated into a single, comprehensive theoretical framework within psychology to explain a general orientation toward authority (Bouchard 2009; Koenig and Bouchard 2006; Ludeke, Johnson, and Bouchard 2013). We build upon this framework to explore two dimensions of ideology (economic and social) and the nature of their shared variance with religiosity and broader first principles for organizing society.

We know that political and religious socialization occurs in families (Clark and Worthington 1990; Cornwall 1989; Jennings and Niemi 1974), that political and religious traits may be partially heritable (Alford, Funk and Hibbing 2005; Vance, Maes and Kendler 2010), and that political attitudes associated with religion are more consistently transmitted from parent to child as compared to other political items (Jennings, Stoker and Bowers 2009; Tedin 1974; Thomas 1971). Why religious and political belief sets are mutually socialized across generations 
and the nature of their possible common biological origins is less developed in multiple academic literatures. In short, we do not fully understand why or how political orientations and religious beliefs co-vary within individuals and across generations.

Rather than thinking about religious beliefs influencing political attitudes through an intentional cognitive process (e.g. The Bible says homosexuality is wrong, therefore I oppose gay marriage) or political attitudes leading to changes in religious affiliation upon entering adulthood (Putnam and Campbell 2012), this study examines whether these belief systems overlap at least in part because they both represent an individual's preferences for "bedrock principles of group life," such as a preference for maintaining traditional moral values in society (Smith, Oxley, Hibbing, Alford and Hibbing 2011b). Our research challenges the prevalent view that religion and politics constitute separate but related belief sets with a conceptual model that explains both political and religious beliefs as rooted in the same underlying psychological construct reflecting first principle beliefs on social organization. Moreover, we also push this challenge further by considering whether part of the relationship between political and religious beliefs is the result of shared genetic influences, which would suggest that a shared predisposition, or set of predispositions, underlies these attitudes. Our model does not exclude socialization and environmental experience as causal influences on the transmission and covariation of political/religious beliefs, since even biological processes occur within some environmental context, but it does conceptualize these belief systems as inter-related rather than wholly independent, and at least partially driven by predispositions toward social order. The purpose of the current paper is to explore the sources of variation in religious and political beliefs within the population and to link these with beliefs about how society should be structured. Using a classic twin design, we are able to examine the source of the shared relationship between 
ideology, religiosity, and preference for traditional social values and show that they covary due to both genetic and environmental factors.

\section{Religion and Politics}

Religious and political belief systems are both means by which individuals organize and understand societies. Political ideology is typically conceptualized as a coherent set of stable beliefs about group life (Jost 2006, see also Converse 1964) or, as Downs put it, "as a verbal image of the good society and of the chief means of constructing such a society” (Downs 1957, 96). Religious beliefs likewise provide a central source of preferences for social rules and order (Emerson and Smith 2000; Hunter 1991; Mockabee, Wald and Leege 2012; Wuthnow 1988). In terms of social beliefs, those on the political left place more emphasis on reducing inequality and promoting progressive social change while those on the right support maintenance of current social hierarchies and traditional values (Haidt 2012; Jost 2006), which in contemporary America includes social inequality resulting from a belief in economic individualism (Jost, Glaser, Kruglanski, and Sulloway 2003). Similarly, when it comes to religion and society, American Christians $^{1}$ on the theological left emphasize social justice here on Earth while those on the theological right focus on an individual's relationship with God and the afterlife (Emerson and Smith 2000; Friesen and Wagner 2012; Hunter 1991; Layman 2001; Smidt, Kellstedt and Guth 2009; Wuthnow 1988).

Traditionally, the religious and the political have been treated as separate but related realms - institutionally, across society, and within individuals. There seems to be evidence that these belief systems have shared elements that may point to individuals possessing a single underlying predisposition toward the organization of society, and at the very least, individuals

\footnotetext{
1 This paper will focus on Christianity as its primary religious system as it is the overwhelming majority religion in the United States (Wald and Calhoun-Brown 2007).
} 
may draw upon similar bedrock principles in forming their religious and political preferences. Preliminary evidence for innate political and religious predispositions has been established in behavioral genetics and can point us to methods for identifying whether these predispositions stem from a common source with each other and with bedrock principles. Though political science traditionally treats behavior and attitudes as products of purposive political socialization from parents, peers, and schools (Jennings and Niemi 1974; Jennings, Stoker and Bowers 2009; Zuckerman, Dasović and Fitzgerald 2007), Alford, Funk, and Hibbing’s (2005) work on the heritability of political attitudes challenged this environmental determinism. This research launched numerous studies demonstrating that political orientations, beliefs, interest, and participation are at least partially heritable and may be linked to specific genes (e.g., Fowler and Dawes 2008; Hatemi, Medland, Morley, Heath and Martin 2007; Settle, Dawes, Christakis and Fowler 2008). Heritability studies do not argue for biological determinism, but indicate that genetics explain some portion of the variance in the transmission of, for example, social and political beliefs across generations in addition to and in concert with environmental factors.

Numerous heritability studies of religiosity have also demonstrated the concurrent influence of genetic and environmental factors on religious beliefs and behaviors. These studies provide a helpful starting point in determining which facets of religiosity may share genetic variance, and therefore a common predisposition, with political attitudes. Two commonly utilized measures of religiosity are religious attendance and religious importance. Whether one attends religious services is at least in part the result of environmental factors, with mixed results on the heritability of religious attendance (Bradshaw and Ellison 2008; Truett, Eaves, Meyer, Heath and Martin 1992). As is often the case with outward behaviors, as opposed to inward beliefs, church attendance seems especially influenced by one's familial environment (Eaves, 
Hatemi, Prom-Womley and Murrelle 2008), but there has been some evidence of genetic effects (Bradshaw and Ellison 2008; Kirk et al. 1999; Kendler and Myers 2009). Within the study of religiosity, the strongest heritability findings have been for specific religious beliefs (such as being born again) and the influence of religious beliefs in one's life, or religious importance (Bouchard, McGue, Lykken and Tellegen 1999; Bradshaw and Ellison 2008). Bradshaw and Ellison (2008) suggest that higher genetic effects for individual beliefs and religious orientations versus outward religious behavior demonstrate that private actions may be motivated more by predispositions and the latter by social influences. For the purpose of this study, these findings suggest that shared predispositions are most likely to occur between political attitudes and religious beliefs, rather than between political attitudes and religious behaviors. The theory that political beliefs may be adopted to satisfy deep-seated psychological needs has been well developed (Jost, Glaser, Kruglanski and Sulloway 2003); the same may be true of religious beliefs, and their correlation with political beliefs may point to a common predisposition or psychological need that is being satisfied by both belief systems.

One of the most comprehensive studies of behavioral genetics and religiosity found significant genetic effects for all seven of their dimensions of religiosity (Kendler, Liu, Gardner, McCullough, Larson and Prescott 2003; Vance, Maes and Kendler 2010). When these factors were entered into a multivariate behavior genetic analysis, results revealed that, "one common genetic factor affects the predisposition to become religious, whereas unique environmental factors shape the specificity of how religiosity phenotypes are expressed” (Vance, Maes and Kendler 2010, 759). In this way, religious attitudes may or may not intersect with, overlap, or influence political beliefs, depending on the environment. If political elites are not tapping into religious frames (Snow, Rochford, Worden and Benford 1986) or individuals are simply 
unengaged in politics - or religion - there may be very little overlap between the two realms. In the American context, where there is considerable covariation between religiosity and political attitudes (Putnam and Campbell 2012; Smidt, Kellstedt and Guth 2009; Wald and CalhounBrown 2007), we could expect to see a shared genetic path between religious and political attitudes that may or may not be found in other societies. For example, measures of religious motivation and belief have been extended to non-religious orientations, such as belief and motivation in the Communist Party in the USSR, and predict similar social attitudes found with these measures on American Christians (McFarland 1998). Though McFarland's (1998) study did not use behavior genetics, the attitudinal similarities across these belief systems suggest that both religious and political beliefs may be adopted to satisfy underlying psychological needs and that these needs may be satisfied by different belief systems in different environments. On this view, certain individuals may have a psychological propensity to approach life based on an organized set of beliefs, and whether this is expressed through religious views, political party affiliations, or something else depends upon their cultural and political environment, how they were raised, and what they encounter as adults. Some individuals may become political, some religious, some both, and some neither.

In one of the few studies of political-religious genetic relationships, Bouchard (2009, 169; Koenig and Bouchard 2006) provides an empirical basis for this explanation by arguing for the presence of a "Traditional Moral Values Triad”, which includes the following: authoritarianism (how families should be organized), religiousness (who controls the universe), conservatism (how societies should be organized). These items strongly correlate, replicate across studies, and demonstrate strong heritability effects. Bouchard explains this phenomenon, “Traditionalism,” as the evolutionary adaptiveness toward obedience and respect for authority, 
aspects of social organization that are foundational to both theology and ideology. Bouchard offers a theoretical and empirical basis for a genetic connection that demonstrates that individuals who believe in a strict religious moral code also enforce a strict code in their homes and expect a similar orientation in society. These connections were demonstrated in a recent study that found a common genetic factor underlying right wing authoritarianism, conservatism on political issues, and religious fundamentalism (Ludeke, Johnson, and Bouchard 2013), suggesting that there is a heritable personality orientation underlying the various scales used in their analysis.

While an important development in the direction of our work, this study focused upon explaining a specific personality type, akin to recent work on the concurrent development of personality and political traits (Verhulst, Eaves and Hatemi 2012), that underlies how individuals express their preferences in the social, religious, and political realms. Our study builds upon this framework by identifying specific paths for shared genetic influence between religiosity, ideology, and bedrock social principles, the latter of which may help with issues of culturally specific constructs (Ludeke, Johnson, and Bouchard 2013). In addition, Ludeke, Johnson, and Bouchard (2013) propose that their examination of traditionalism or obedience to authority may uncover one factor behind religious and political beliefs but that this factor is likely separate from a related but different trait regarding egalitarianism or economic issue preferences (Funk et al. 2013). By distinguishing internal religious beliefs from external religious behaviors, separating social and economic ideology, and examining three distinct sets of bedrock social principles, we are able to demonstrate that genetics explain covariation between some of these variables, but not others. This approach gives us additional insight into why political attitudes 
and religious beliefs co-vary by identifying not only where genes play a role, but also where they do not.

In summary, numerous studies show that religious beliefs and individual-level political attitudes are correlated, and that religious and political beliefs are transmitted across generations. Yet though these belief systems are clearly related within individuals and across generations, they are overwhelmingly conceptualized and studied as independent constructs that are exclusively products of purposive socialization and environmental experience. We challenge this traditional view with a conceptual model that explains political and religious beliefs as arising in part from the same underlying psychological construct that reflects first principle beliefs on social organization, resulting in mutually reinforcing beliefs in both the political and religious realm. We argue that these three constructs share common genetic and environmental underpinnings. This model does not exclude socialization and environmental experience as causal influences on the transmission and co-variation of political/religious beliefs, but it does conceptualize these belief systems as inter-related rather than wholly independent, and at least partially driven by genetic predispositions toward social order.

The purpose of the current study is to explore the sources of variation within the population for the overlap of religious and political beliefs. Using a classic twin design, we are able to partition this sample's variance into influences due to genetics, the shared environment, and the unshared environment, concluding that the source of the shared relationship between the political and the religious is quite dependent on the measure at hand. That is, some political and religious relationships are more due to genetics, some to the environment, and some both.

\section{Hypotheses and Methods}


We hypothesize that political beliefs, religious beliefs, and bedrock social principles are heritable, and more importantly, that the correlation between these variables is at least partially explained by a common genetic pathway. These hypotheses will be tested using a classic twin design with the Survey on Social and Political Issues through the Minnesota Twin Family Registry, a birth-record based registry containing approximately 8,000 twin pairs born in Minnesota from 1936 to 1955; our sample only includes those born in 1947 through 1955. Thus, the twins in this study ranged in age from 53 to 61 years. The Survey on Social and Political Issues is publicly available data gathered between July 24 and December 22, 2008, and July 13 to October 30, 2009. The University of Minnesota implemented data collection with a postal mail invitation and follow-up letter, and respondents were offered a \$35 incentive for their participation in 30- to 40-minute survey. Most respondents engaging a web survey - though a paper questionnaire was available to a few respondents in 2008 who had limited access to the Internet. All 146 respondents used paper surveys during the 2009 collection period. When combining the two survey periods, there were 1,349 individuals who completed the questionnaire, including 1,192 members of twin pairs where both individuals responded to the survey and 157 had a twin that did not complete the survey. We limit our sample for the following analyses to the 1,192 respondents that were part of a matched twin pair.

\section{Measures}

Because attitudes on issues of the day can vary generationally and culturally, we were interested in testing whether broader measures of bedrock principles might underlie both political and religious beliefs and help to explain the overlap between the two. For example, a WilsonPatterson battery used below and in the Ludeke, Johnson, and Bouchard (2013) study would measure attitudes on items like gay marriage, which similarly to issues of segregation of the past, 
will vary by age cohort. Smith et al. (2011b, 381) developed a "Society Works Best” (SWB) index to tap a psychological construct argued to be the basis of political ideology by addressing "the core dilemmas facing all mass-scale societies." Admittedly, this forced choice measure (detailed below) is novel and newly tested, providing some limitations on scale reliability. Nevertheless, it is an effort to generate a measure that is not dependent on cultural context or time period and has been replicated in twin samples in the United States and Australia and correlates, but does not perfectly overlap, with self-reported ideology, party identification, and policy preferences (for more on this scale, see `, Smith, and Alford 2014).

The Society Works Best questions provide respondents a forced choice between two options, such as "Society works best when people live according to traditional values or people adjust their values to fit changing circumstances.” The original authors of the scale sought to put together a battery of items that ranged from preferences on fixed or fluid values, notions of leadership (which would be similar to other authoritarian measures), and whether the group or individual is valued more. In this way, the Society Works Best battery seeks to define societal and political orientations beyond the dimensions of concepts similar to Right Wing Authoritarianism or Social Dominance Orientation. A factor analysis on the inaugural SWB survey (in a separate study) revealed a five-factor solution, which Smith et al. (2011b) labeled along the following dimensions: Traditional values/moral codes, outgroups/rulebreakers, role of group/individual, leadership, and absolutes. After conducting a principal components analysis on the twin dataset, three factors emerged with eigen values over 1 that fit into theoretical categories reflecting the following concepts: traditional values/moral codes, role of group/individual, and leadership. Items that loaded on the absolutes factor in Smith et al. (2011b) collapsed into the traditional values/moral codes factor, and the items from Smith et al.'s outgroups/rulebreakers 
factor loaded onto the group/individual factor - thus, this scale seems to be capturing basic ideas about moral codes, groups, and leaders. The twin dataset is a larger sample (1,171 vs. 200), and this reduced factor solution makes intuitive sense in the way the questions combined to form three ways of thinking about how society should be organized. Thus, while the factor structure of the Society Works Best battery is not the central focus of this paper, we note that researchers may want to investigate in the future the possibility that a three-factor structure is most appropriate.

Each item was coded 0 for the more liberal position (e.g. "Society works best when people assume that all those in far away places are kindly") and 1 for the more conservative answer (e.g. "Society works best when people realize the world is dangerous"). These scores were combined into an additive index for all items - SWB Full - and three additive subscales for the categories of SWB Values, SWB Group, and SWB Leader. We consider both the full scale and the subscales in the analyses below. Because the SWB Values subscale will emerge as the focus of the majority of our models, we wish to put this measure in the context of other psychological or social scientific question batteries. The spirit of several of the SWB Values questions may capture some of the same latent preferences of Right Wing Authoritarianism, but the language used in SWB is more general and simplified as compared to RWA questions, such as "It is always better to trust the judgment of the proper authorities in government and religion than to listen to the noisy rabble-rousers in our society who are trying to create doubt in people's minds” (Altemeyer 1981). In this way, SWB could possible avoid some of the criticisms scholars have lodged at RWA (Ray 1989) for use of heavy-handed wording and measurement suggesting “conservatism is being held up as a pathology by the left-leaning denizens of academic psychology” (Hibbing, Smith and Alford 2013, 103). 
Though political attitudes and behavior were the focus of the twin survey used in this analysis, there were several religiosity measures included. We decided to select an internal or belief-oriented measure of religiosity -- importance of religion in one's life (m=0.64, SD=.33) as well as an external or behavior-oriented measure, frequency of religious service attendance $(\mathrm{m}=0.52, \mathrm{SD}=0.29) .{ }^{2}$ Because certain religious measures or political items may be more heritable than others and represent distinct psychological constructs (Bradshaw and Ellison 2008), we do not collapse them together as this may obscure whether there is a shared genetic or environmental path between certain items and not others. For example, the correlation between religious service attendance and political attitudes or first principles may be best explained by environmental effects, since attendance is a behavior and behaviors are often found to be less subject to genetic effects (Bradshaw and Ellison 2008). By contrast, an internal belief like the importance of religion in one's life may overlap with political items partially due to genetics.

We measure political ideology with a set of questions designed to capture political conservatism, as measured by a Wilson-Patterson inventory (Wilson and Patterson 1968; see online codebook for the version used). The full scale is designed to measure political conservatism broadly defined, but the multi-item format also allows us to separate out social and economic ideology.

A correlation matrix of the key variables is displayed in Table 1 and the cross-twin correlations for MZ and DZ twins are displayed in Table 2. Importance of religion is positively

\footnotetext{
${ }^{2}$ Religious affiliation (identification of Protestant, Catholic, etc.) is excluded from this analysis because the categories are too broad to tap into dimensions related to the overlap between religious and political beliefs. The other two religious options were self-identification as born again, which we excluded because it is a dichotomous variable and the methods used here assume normality, and self-identification as a spiritual person, which we excluded due its lack of variance ( $85 \%$ of the sample indicated yes, they were spiritual, including a number of religious individuals).
} 
related with the Full SWB battery, conservative political ideology, and their subscales (with the exception of SWB Group), such that higher scores on the religious measures are associated with more conservative views on how society should work. Next, we turn to partitioning the variance between these measures into environmental and genetic components.

[Table 1 and Table 2 about here]

\section{Methods}

In this study, we rely on a classic twin design to examine the genetic and environmental covariance between bedrock social principles, political ideology, and religiosity. Classic twin designs focus on population variance, rather than population means, in order to decompose the covariance between twins on a given trait into genetic, shared environmental, and unique environmental components (Medland and Hatemi 2009). The genetic component explains how much of the similarities between individuals on a specific trait are due to "gene-based predispositions, needs, wants, desires, or motivations” (Bradshaw and Ellison 2008, 531). The shared environment accounts for the portion of similarity that stems from twins being raised within the same families and reflects all of the influences in their environment that they have in common. The unique or unshared environment refers to any experience that is not shared between the twins, whether it is differences realized during childhood or as adults.

A classic twin design is a natural experiment that uses a handful of simple assumptions to estimate these parameters: the difference in genetic relationships between monozygotic (identical) and dizygotic (nonidentical) twin pairs raised together and the similarity of their common environments. Specifically, monozygotic (MZ) twins are assumed to share all genetic variance because they come from a single fertilized egg, while dizygotic (DZ) twins are assumed to share $50 \%$ of their genes (on average) because they come from two fertilized eggs. Secondly, 
the equal environments assumption posits that the shared environments of twin pairs (parents, schools, friends, time period, geographic region, etc.) have the same influence on the traits being studied, regardless of whether the twins are MZs or DZs. Though MZ twins may be treated more similarly than same-sex DZ twins (e.g., more likely to be dressed alike), what is important is that this type of treatment or shared experience will not affect the trait in question - which seems to be the case for political and social attitudes that will be examined here (Smith, Alford, Hatemi, Eaves, Funk and Hibbing 2012). What varies in the model, then, is the number of genes shared by the twin pairs.

As mentioned above, $\mathrm{MZ}$ twins share $100 \%$ of their genes and $\mathrm{DZ}$ twins share, on average, around $50 \%$ of their genes, the same as non-twin siblings. In comparing the difference in the correlations between each MZ and DZ twin pair, higher correlations for monozygotic twins relative to dizygotic twins indicate that a portion of that trait's variance may be due to genetic influences. If the correlations between the two types of twin pairs are very similar, then the resemblance will be due to common environmental experiences, as all twin pairs were raised together. Finally, if there is little relationship between twins on a certain trait, we can conclude that unshared or unique environmental experiences are influencing that trait.

[Figure 1 about here]

In order to test the relationship among political ideology, the Society Works Best index, and religiosity, we conduct a series of twin models using OpenMx for R (Boker, Neale, Maes, Wilde, Spiegel, Brick, Spies, Estabrook, Kenny, Bates, Mehta and Fox 2011), including univariate, bivariate, and trivariate twin models to characterize the variance in each trait; the goals of each of these models are presented conceptually in Figure 1. Using structural equation modeling, the unit of analysis is the twin pair, and the comparison of the variance decomposed 
into genetic (A), shared environment (C) and unique environment (E) components from MZ to DZ twins is akin to the between-groups and within-groups comparison in an ANOVA (Medland and Hatemi 2009; Smith et al. 2012). The "E" term also encompasses measurement error in the model. Structural equation modeling was used to develop a saturated model, then a full ACE model and AE, CE, and finally E submodels. This model-fitting process allows for measures of statistical significance to provide confidence in the results. For example, if the full ACE model is not significantly different from the fully estimated, saturated model, then we can be more confident in the results produced from this well-fitting model. Moreover, if we drop the various other components (A, C, or E), we can test the resulting model against the ACE model to determine whether model fit has significantly improved or deteriorated. Under this procedure, the best-fitting model is the model which utilizes the least parameters without significantly reducing the model fit when compared to models which leave the parameters unconstrained. In other words, the best-fitting model is the model that is most parsimonious while still fitting the data.

The univariate analyses for each variable serve three purposes. First, they provide an initial estimate of the degree to which each trait (e.g., religious importance) is the result of genetic and environmental factors (i.e., the bolded paths in Figure 1A). Second, they provide a baseline against which the more complicated bivariate and trivariate models can be compared. In particular, we checked for large deviations in estimates of the total heritability of a trait, which might indicate problems with the models. Third, the univariate models allow us to select variables for subsequent analysis that are more likely to have the comparable variance structures. Correlated variables with similar variance structures are appropriate to model simultaneously in 
order to identify common variance components (e.g., two variables that reduce to an AE model, rather than one that reduced to an AE model and another that reduced to a CE model).

Following the univariate analyses, the second set of analyses presents a series of bivariate Cholesky decompositions (see Medland and Hatemi 2009). The bivariate models allow us to compare the extent to which the genetic and environmental factors underlying these variables are shared in common. In other words, a bivariate model can determine whether the genetic and environmental factors that lead to higher religious importance also lead to greater political conservatism (i.e., the bolded paths in Figure 1B). It also estimates the extent to which there are other genetic and environmental factors which influence religious importance but do not influence political ideology, or vice versa.

An alternative (but statistically identical) way to conceptualize the bivariate models is as correlated factor models that decompose the correlation between two variables into its genetic and environmental components (see Loehlin 1996). This approach asks whether the genetic factors underlying one variable are correlated with the genetic factors underlying a second variable (i.e., the bold paths in Figure 1C). If these genetic paths are correlated, then part of the correlation between the two variables is due to shared genetic factors. For example, is the observed correlation between religious importance and political conservatism the result of genetic factors that affect both variables, environmental factors that affect both variables, or some combination of both genetic and environmental factors? From this perspective, just as the univariate model aims to decompose the variance in a trait into genetic and environmental components, the bivariate model aims to decompose the covariance between two traits into genetic and environmental components. 
Finally, the trivariate model decomposes the variance of three variables simultaneously. The added benefit of this approach, above and beyond the univariate and bivariate models, is that it can determine whether there is a single genetic or environmental source of variance that underlies all three variables jointly (i.e., the bolded paths in Figure 1D). A common genetic path may imply that there is a predisposition that causes these traits to co-occur, whether directly, mediated through one of the measured traits (e.g., the one that emerges earliest), or through some earlier, unmeasured trait. A common unique environmental pathway may imply that there is some set of individual experiences that causes these traits to co-occur, but that these experiences are not shared across siblings or at least have unrelated impacts on siblings. We provide full model estimates for ACE, AE, and CE specifications for all analyses in appendix Tables 1, 2, and 3, for univariate, bivariate, and trivariate analyses, respectively.

\section{$\underline{\text { Univariate results }}$}

The univariate results allow us to get a view of which variables have heritable components and which variables do not in order to appropriately narrow the search for genetic covariance between traits in the bivariate and trivariate analyses. This section examines several measures of religiosity, political ideology, and preferences about how society should be organized. Although we estimated several different models for each variable, for brevity and clarity of presentation we do not report every estimated parameter below. Full univariate model estimates for ACE, AE, and CE specifications for all variables discussed here are available in appendix Table 1.

Religiosity

We examine two measures of religiosity in our data. First, we consider the importance of religion in one's life, which is an attitudinal variable that captures an individual's orientation 
towards religion. When we estimate a full ACE model, we find a significant genetic component (A, $42.4 \%$ of the variance in religious importance; 95\% CI: 11.5 - 55.5), a significant unique environment component (E, 52.1\% of the variance; 95\% CI: 44.5 - 61.0), and a non-significant common environment component (C, 5.6\%; 95\% CI: 0 - 31.2). ${ }^{3}$ This model suggests that there is little to no variance in religious importance that can be attributed to common environment effects (i.e. environmental factors that impacted equally on both twins), supporting the literature on the heritability of internal or belief-oriented phenotypes of religiosity (Bradshaw and Ellison 2008). The result reflects the fact that the correlation among monozygotic twins' religious importance is much higher than the correlation among dizygotic twins' religious importance (see Table 2). We next estimate a more parsimonious AE model, which constrains the $\mathrm{C}$ component to zero, and find that it does not significantly decrease the model fit $\left(p_{\mathrm{ACE}}=0.65\right)$. Therefore, we treat the AE model as the best-fitting model for religious importance. This model divides the variance in religious importance about equally between genetic and unique environmental factors ( $\mathrm{A}=$ 48.4\%, 95\% CI: 40.1 - 55.7; E = 51.6\%, 95\% CI: 44.3 - 59.9). Thus, we conclude that both genetic and unique environmental factors play a significant role in religious importance.

Second, we consider religious attendance, a self-reported behavioral variable that captures the regularity of attending religious services. When we estimate a full ACE model, we find a significant common environment variance component (C, 29.8\%; 95\% CI: 3.5 - 50.5), a significant unique environment component (E, 48.5\%; 95\% CI: 41.4 - 56.9), and a moderate, but statistically insignificant genetic effect on religious attendance (A, 21.7\%; 95\% CI: 0 - 51.2). For religious attendance, an AE model has a significantly worse fit than an ACE model $\left(p_{\mathrm{ACE}}=\right.$

\footnotetext{
${ }^{3}$ Because the results presented here are reported as a percent of the variance accounted for in a trait, the confidence interval on these estimates cannot extend below zero. To determine if a coefficient is significant, we utilized the $95 \%$ confidence interval around the standardized path coefficients reported in Tables 1, 2, and 3 of the appendix.
} 
0.01). Therefore, between the ACE and AE models of religious attendance, the ACE model is to be preferred due to its improved fit, even though it is less parsimonious than the AE model. The CE model, which constrains the genetic A component to zero, has only a marginal decrease in fit when compared to a full ACE model $\left(p_{\text {ACE }}=0.07\right)$. We interpret the CE model as the best-fitting model for religious attendance. This model divides the variance in religious attendance about equally between common environmental and unique environmental factors ( $\mathrm{C}=47.1 \%$, 95\% CI: 40.2 - 53.3; $\mathrm{E}=52.9 \%, 95 \% \mathrm{CI}: 46.7$ - 59.8). The CE model suggests that there is little to no variance in religious attendance that can be attributed to genetic factors. The result reflects the fact that the correlation among monozygotic twins' religious attendance is approximately the same as the correlation among dizygotic twins’ religious attendance (see Table 2).

Thus, religious importance and religious attendance appear to have different variance structures. Both have large unique environmental effects, suggesting the impact of idiosyncratic life experiences on the development of religious importance and religious attendance. Although the estimates of the unique environment components of these variables will also be somewhat inflated due to measurement error (since both religious importance and religious attendance were measured with single items), the models do find significant genetic and common environment effects, respectively. The models that best fit these data suggest that religious importance is heritable and has a negligible common environmental component, while religious attendance is not heritable and has a large common environmental component. These differences replicate some prior research on the heritability of religiosity. Church attendance (when not combined as part of an index) has been found to be primarily a result of both shared and unique environmental influences (Truett et al. 1992), though some studies have reported genetic effects (Bradshaw and Ellison 2008; Kirk et al. 1999; Kendler and Myers 2009). The variance in the importance of 
religion in guiding one's life is divided between genetics and the unique environment (Bradshaw and Ellison 2008). Because church attendance has no significant genetic component, we exclude this variable from further analysis that seeks to determine whether there is shared genetic variance among religiosity, political attitudes, and first principle beliefs. Instead, we focus the analysis on the relationship of these other variables to religious importance.

\section{Bedrock values}

We also conducted univariate analyses on several measures of what we consider first principles, or the respondents' fundamental views about how society should be organized, as measured by the Society Works Best (SWB) index and its subscales. The full scale is designed to measure views across the political spectrum, with the SWB Group subscale capturing views on the role of the indiviudal and the group and the SWB Values subscale representing preferences for stability of beliefs or external standards of behavior. ${ }^{4}$ The best-fitting models are AE for the Full SWB scale ( $p_{\text {ACE }}=1.00 ; \mathrm{A}=38.0 \%, 95 \%$ CI: 28.7 - 46.3; $\mathrm{E}=62.0 \%, 95 \%$ CI: 53.7 - 71.3), the SWB Group subscale ( $p_{\mathrm{ACE}}=1.00 ; \mathrm{A}=34.4 \%, 95 \%$ CI: 24.7 - 43.2; $\mathrm{E}=65.6 \%$, 95\% CI: 56.8 - 75.3), and the SWB Values subscale ( $p_{\mathrm{ACE}}=1.00 ; \mathrm{A}=38.6 \%$, 95\% CI: $29.2-47.0 ; \mathrm{E}=$ 61.4\%, 95\% CI: 53.0 - 70.8). ${ }^{5}$ All of these models suggest that these fundamental values contain a significant heritable component, albeit one that is smaller than the unique environmental

\footnotetext{
${ }^{4}$ We do not report results for the leadership subscale because the low variance and high skew in this sample render this variable inappropriate for methods that assume normality.

${ }^{5}$ For the full scale and group subscale of the Society Works Best index, the MZ correlation is more than twice the $\mathrm{DZ}$ correlation. This suggests that it may be more appropriate to run ADE models for these variables, which estimate dominance effects (D) that capture certain types of gene by gene interactions instead of common environment effects. However, because it is not possible to estimate common environment and dominance effects simultaneously without an extended twin family design, and because our hypotheses do not hinge on whether the genetic effects that we are examining are additive or non-additive, we instead report ACE and AE models for all variables. In these models, we interpret the $\mathrm{A}$ as an estimate of broad-sense heritability, which includes both additive and non-additive genetic effects (see Coventry and Keller 2005).
} 
component of the variance in each case. Moreover, we find no significant common

environmental component in these variables.

\section{Political Ideology}

In examining the Wilson-Patterson battery of political attitudes, the best-fitting model for the full scale was an AE model $\left(p_{\mathrm{ACE}}=0.51 ; \mathrm{A}=65.1 \%, 95 \% \mathrm{CI}: 58.7-70.5 ; \mathrm{E}=34.9 \%, 95 \%\right.$ CI: 29.5 - 41.3). This model suggests that political issue attitudes are highly heritable, and that common environmental influences do not play a significant role. These results are consistent with past research (Alford, Funk and Hibbing 2005). Moving beyond previous behavioral genetic studies of political ideology, we also divided political attitudes into social and economic components (Carmines, Ensley, and Wagner 2012; Feldman and Johnston 2014; Miller and Schofield 2003). These were constructed by creating a social ideology subscale (12 items, $\alpha=$ 0.84 ) and an economic ideology subscale ( 3 items, $\alpha=0.54){ }^{6}$ These scales were moderately correlated $(r=0.40)$. We also created a measure of social ideology that is free of economic preferences and a measure of economic ideology that is free of social preferences by regressing these scales on each other, and keeping the residuals. By comparing the results of the full and residualized measures we can gain a richer picture of the relationships between political ideology, religiosity, and core values.

For the non-residualized measures, we find greater heritability in social ideology $\left(p_{\mathrm{ACE}}=\right.$ 0.23; $\mathrm{A}=63.3 \%$, 95\% CI: 56.9 - 68.8; $\mathrm{E}=36.7 \%, 95 \%$ CI: 31.2 - 43.1) than in economic ideology $\left(p_{\text {ACE }}=0.73 ; \mathrm{A}=39.2 \%, 95 \% \mathrm{CI}: 30.2\right.$ - 47.3; $\mathrm{E}=60.8 \%$, 95\% CI: 52.7 - 69.8), but no

\footnotetext{
6 The lower reliability of the economic ideology measure likely contributes to the higher unique environment component $(\mathrm{E})$ in this measure. However, despite the lower reliability, we are able to find significant genetic effects on economic preferences in many of the analyses. Moreover, economic ideology may simply have less internal consistency than social ideology or suffer from greater measurement error (Ansolabehere, Rodden, and Snyder 2008), as evidenced by the lower median heritability among the single economic items as compared to the single social items.
} 
significant role of common environment effects in either. These results suggest that both social ideology and economic ideology have heritable components, but that genetic factors may play a greater role in social ideology. When we consider the residualized measures (e.g., economic ideology removing the covariance with social ideology), we still find greater heritability in social ideology $\left(p_{\mathrm{ACE}}=0.16 ; \mathrm{A}=50.8 \%, 95 \%\right.$ CI: $42.7-57.8 ; \mathrm{E}=49.2 \%, 95 \%$ CI: $\left.42.2-57.3\right)$ than in economic ideology $\left(p_{\mathrm{ACE}}=0.49 ; \mathrm{A}=26.9 \%, 95 \%\right.$ CI: 16.8 - 36.3; $\mathrm{E}=73.1 \%$ 95\% CI: 63.7 83.2) and no significant role of common environment effects in either. The reduced heritable components in both residualized models indicate that the shared variance may have a sizeable genetic component. In addition, the residualized models suggest that both types of ideology have significant heritable components that are unshared with the other type.

The univariate results for social ideology, Society Works Best values, and religious importance are displayed graphically in Figure 2.

[Figure 2 about here]

\section{Bivariate Results}

[Figure 3 about here]

The bivariate analyses aim to parse the covariance between religious importance and the ideological and Society Works Best variables discussed above into its genetic and environmental components. In other words, these analyses partition the observed correlation between religious importance and the other variables into genetic, common environment, and unique environment components. These correlations can give us insight into why these social and political variables are related to religiosity. As in the univariate results, the best fitting bivariate models for religiosity and these other variables were AE models, so we limit our discussion of common 
environment effects below. Full bivariate model estimates for ACE, AE, and CE specifications for all analyses are available in appendix Table 2.

In order for bivariate models to parse the covariance between two variables into its components, there must be some observed covariance between the variables (i.e. the variables must be correlated). We find that, on average, individuals with more conservative policy views and with more conservative bedrock principles place higher levels of importance on religion in their lives than individuals with liberal views (see Table 1). Although there are significant correlations between the religious importance and the full Society Works Best scale and the full Wilson-Patterson, by examining the subscales, it is possible to determine that these correlations are being driven by specific components of the full scale measures. Specifically, we find stronger correlations of religious importance with the SWB Values subscale and with the social ideology component of the Wilson-Patterson than the full-scale measures. Conversely, we find that the SWB Group subscale is not significantly correlated with religious importance and that the economic ideology component of political ideology is only weakly correlated with religious importance (see Figure 3A). However, the weak correlation between economic ideology and religious importance is no longer significant when the covariance between social ideology and economic ideology is removed. Because the uncorrelated components of the full scales cannot logically contribute to the genetic or environmental covariance between the full scales and religious importance, we exclude the groups subscale from further analysis and focus on partitioning the covariance of religious importance with traditional values, social conservatism, and economic conservatism. These results suggest that while constructing a broader scale of religiosity or ideology may be a valuable approach to some research questions, focusing on the components of these larger belief systems may provide additional insight that would otherwise 
be obscured (e.g., into the pathways through which genetic and environmental influences can contribute to covariation).

The bivariate analysis of religious importance and social ideology shows that the correlation between these two variables is driven by both genetic and environmental factors (see Figure 3B; Figure 3C shows the full AE model). The AE model, which constrains the C component to zero, has no significant decrease in fit when compared to a full ACE model ( $p_{\text {ACE }}$ $=0.43$ ) and may be interpreted as the best-fitting model for these two variables. The AE results show that of the total variance in social ideology, $24.7 \%$ is accounted for by genetic effects that are shared with religious importance (95\% CI: 17.1 - 33.2) and 6.3\% is accounted for by unique environment effects that are shared with religious importance (95\% CI: 3.7 - 9.7). When we consider the AE results for the residualized version of the social ideology measure (having removed the covariation with economic ideology, $\left.p_{\mathrm{ACE}}=0.27\right)$, we find similar results $(\mathrm{A}=$ 21.2\%, 95\% CI: 13.9 - 29.6; $\mathrm{E}=6.3 \%$, 95\% CI: 3.3-10.4). These results suggest that, even having removed the covariation between social and economic ideology, the connection between social ideology and religious importance is primarily genetic.

The conclusions from the bivariate analysis of religious importance and economic ideology are somewhat different. With the unresidualized measure of economic ideology, the AE model suggests that a statistically significant portion of the variation in economic ideology is caused by a genetic effect that is shared with religious importance (A = 4.5\%, 95\% CI: $1.4-9.6)$ and that the correlation between these variables is not caused by unique environmental effects that impact on both variables ( $\mathrm{E}=0.0 \%, 95 \% \mathrm{CI}: 0-1.0$ ). However, when we remove the covariation between economic ideology and social ideology, the genetic effect that is shared between religious importance and economic ideology is no longer present $(\mathrm{A}=0.0 \%, 95 \%$ CI: 0 
- 1.1). Taken together, these analyses suggest that insofar as economic ideology and religious importance are correlated, this correlation is genetic, and that this genetic correlation is also shared with social ideology. We test this interpretation directly in the trivariate section below.

Turning to the values sub-scale of the Society Works Best index, the bivariate analysis of religious importance and SWB Values shows that the correlation between these two variables is also driven by a mix of genetic and environmental factors. The AE model, which constrains the C component to zero, has no significant decrease in fit when compared to a full ACE model $\left(p_{\mathrm{ACE}}=0.96\right)$ and may be interpreted as the best-fitting model for these two variables. Again, of the total variance in religious importance, a majority of the variance that is shared with SWB Values is genetic. However, only a smaller percentage of the total variance in religious importance is shared with SWB Values (10.7\%).

There are several noteworthy features of these results. First, in all models, the correlation between religious importance and conservatism was driven primarily, but usually not exclusively, by genetic factors. Nearly $40 \%$ of the total genetic variance in social ideology is shared with religious importance; by contrast, less than $20 \%$ of the total unique environmental variance in social ideology is shared with religious importance. These findings leave open the question as to what types of life experiences may play a role in religious importance. Second, in both models, the majority of the variance in religious importance is unshared with the other variable (e.g., $87.2 \%$ of the variance in religious importance was accounted for by components that are unique to religious importance in the bivariate analysis with traditional values), ${ }^{7}$ indicating that there is still much of the religious that is not explained by first principles or

\footnotetext{
${ }^{7}$ For the relationship with social ideology and economic ideology, we can determine the proportion of variance in religious importance that is unshared with these variables by reordering the variables in the model so that religious importance is the second variable. This procedure is discussed in greater detail in the trivariate analysis section.
} 
political attitudes. This is not contrary to our hypothesis as we are not suggesting a perfect overlap between the two frameworks.

In sum, the bivariate results suggest that both genetic and unique environmental factors underlie the correlations of religious importance with social ideology and SWB values. The large genetic component in these relationships suggests that there may be a common underlying

predisposition that leads individuals to adopt conservative bedrock social principles and political ideologies while simultaneously feeling the need for religious experiences. Importantly, these relationships with religiosity only hold when we consider social ideology and a preference for stable values in organizing society, and much more weakly or not at all when we consider economic attitudes or attitudes toward individuals and groups in the organization of society.

\section{$\underline{\text { Trivariate results }}$}

The bivariate models leave open a key question: are the genetic/environmental factors that impact jointly on religious importance and social policy attitudes the same genetic/environmental factors that impact jointly on religious importance and traditional moral values, or are these two distinct pathways from genes to religious importance? The trivariate model addresses this question by testing for a genetic path that is common to all three variables. Full trivariate model estimates for ACE, AE, and CE specifications for all analyses are available in appendix Table 3.

[Figure 4 about here]

Our findings confirm the existence of a common genetic factor that underlies holding socially conservative policy positions, maintaining traditional values, and placing importance on religion in one's life. If we order the variables in the presumed causal order (traditional values to religious importance to social ideology, see Figure 4A), the ACE model suggests that there is a 
genetic component that is shared by these three variables and that accounts for $37.1 \%$ of the variance in social ideology (95\% CI: 11.4 - 63.2). For comparison, the unique environmental component that loads on all three variables accounts for $5.9 \%$ of the variance in social ideology (95\% CI: 3.3 - 9.4). In the AE model, which is best-fitting $\left(p_{\mathrm{ACE}}=0.41\right)$, this shared genetic component accounts for $34.1 \%$ of social ideology (95\% CI: 24.7 - 44.4). In addition, there is a genetic component that is uniquely shared between religious importance and social ideology that accounts for $6.9 \%$ of social ideology (95\% CI: 2.6 - 12.5). The AE results suggest that nearly $65 \%$ of the genetic variation in social ideology is shared with religious importance and traditional values, compared to about $25 \%$ of the environmental variation in social ideology. For economic ideology, a similar AE model finds that less than $20 \%$ of the genetic variation and around $5 \%$ of environmental variation in economic ideology is shared with religious importance and traditional values.

Re-ordering the variables in the trivariate model does not affect model fit; statistically, the models are identical. However, it can provide insight into how genetic and environmental variation is shared between the different variables. A model which places social ideology first, followed by traditional values and religious importance, allows us to address the following question: is there any variation in religious importance that can be explained by the traditional values measure above and beyond what is already accounted for by social ideology? Both the ACE model and the better-fitting AE model $\left(p_{\mathrm{ACE}}=0.41\right.$, as above $)$ show that the genetic and environmental factors that are shared between traditional values and religious importance are also fully shared with social ideology. This is indicated in the model because the paths from the A1 and E1 components to religious importance are significant and, simultaneously, the paths from the A2 and E2 components to religious importance are not significant (see Figure 4B). 
Even so, in the AE model, the genetic component that is shared by social ideology, traditional values, and religious importance accounts for only about $40 \%$ of the genetic variance in religious importance and less than $20 \%$ of the total variance in religious importance. The unique environmental component that is shared by all three variables accounts for about $16 \%$ of the unique environmental variance in religious importance and about $9 \%$ of the total variance in religious importance. Though these components account for a sizeable portion of the variance in religious importance, the bulk remains unaccounted for.

In addition to this shared genetic variance, the results also indicate that there are genetic influences that are unique to each variable. As indicated above, the majority of the genetic variance in religious importance is not shared with social ideology or one's orientation toward traditional values. This points to the need to identify other variables which may share a common genetic pathway with religious importance or which may act as mediators of the effect of genetic factors on religious importance. This same research agenda applies to the study of political ideology and bedrock social principles.

The focus on the genetic pathways above should not detract from the consideration of environmental factors. In fact, one of the benefits of utilizing a classical twin design is that it provides insight into the environmental factors that contribute to variance as much as it does to genetic factors. Our results indicate that social ideology, religious importance, and traditional values also share a common unique environmental factor. This suggests that there are some environmental influences or experiences that cause these variables to covary. Although this factor is of less substantive significance than the genetic factor, as indicated by the smaller crosstrait path loadings from the E components in Figure 4, it is still statistically significant and deserving of attention in future research. 
In sum, these findings provide support for the hypothesis that there is a common predisposition or set of predispositions that underlie these three variables, and future research should seek to identify both the genetic and environmental factors that influence these traits individually. However, while these common factors account for a significant portion of the variance in each trait, it should be noted that each trait also has genetic and unique environmental components that are unshared with the other two traits.

There is one further insight that can be gleaned from the trivariate modeling approach. If we model social ideology, economic ideology, and religious importance, we can test directly whether economic ideology has any relationship with religious importance above and beyond its shared variance with social ideology. The results, as with those for traditional values discussed above, suggest that the genetic and environmental factors that are shared between economic ideology and religious importance are also fully shared with social ideology. This is indicated in the model because the paths from the A1 and E1 components to religious importance are significant and, simultaneously, the paths from the A2 and E2 components to religious importance are not significant (see Figure 4C). In sum, these data suggest that the observed correlation between economic ideology and religious importance is fully accounted for by part of the relationship between social ideology and religious importance.

\section{Discussion}

In our sample, certain religious, political, and first principle beliefs can be explained by genetic and unique environmental components, and the correlation between these three trait structures is primarily due to a genetic path. These findings provide evidence that the overlap between the religious and the political in the American context may be due to underlying principles regarding how to understand and organize society and that these principles may be 
adopted to satisfy biologically-influenced psychological needs (Jost et al. 2003; Ludeke, Johnson and Bouchard 2013). However, despite these shared influences, there is still a significant amount of genetic and environmental variation in these traits that remains to be accounted for, which suggests that future research should continue to explore alternative pathways in explaining these variables.

The existence of genetic and environmental factors that link these traits indicate that a common predisposition, some other trait, or possibly some combination of traits, may be a significant contributor to the development of these three belief systems. Moreover, future research that searches for variables that explain the effect of genes on political ideology should move beyond considering only Big Five personality traits and consider other variables like religiosity. Indeed, psychologists and social scientists have suggested that even though there are small effect-size associations between religiosity and personality trait schemes like the Big 5 (Robbins, Francis, McIlroy, Clarke and Pritchard 2010; Francis 2010; Hills, Francis, Argyle, and Jackson 2004; Saroglou 2002), religiosity is quite possibly a separate trait dimension that is not wholly represented by openness, conscientiousness, extraversion, agreeableness and emotional stability (Mondak 2010; Saucier and Goldberg 1998). Yet, religiosity has clear ties to various political attitudes and behaviors and is thus an important construct to explore in trying to understand the origins and dimensions of ideology.

Future research should also seek to generalize our findings by replicating them in more diverse samples and with multi-item measures of religiosity. The nature of the sample (middle aged, largely white, largely Midwestern) leaves open questions regarding whether the link between religiosity, values, and political ideology is conditional on generational differences, age, racial and class dynamics, or regional and cross-national factors. Addressing these questions 
would significantly advance our understanding of the interconnections among these variables. In addition, although we were restricted to a single-item measure of religiosity in this sample, future research should consider what can be gained from utilizing a multi-item measure of religiosity in a genetically information sample (see also Ludeke, Johnson, and Bouchard 2013). The differences that we find between social and economic ideology are instructive on this point, as they would have not been detected had we used a single-item measure of political ideology. Unfortunately, few datasets exist that contain a breadth of religious and political measures.

An alternative explanation to our study may be that individuals interpret saying religion is an important guide in one's life and agreeing that "Society works best when people live according to traditional values” as the same thing. But this is precisely our point. The SWB battery does not prime respondents for religion and, with its set up, seeks to ask respondents to not think of how "I work best” or "how I want to live my life," but rather how communities should function. That is, individuals may tend to separate the personal, interpersonal, and political realms (Alford and Hibbing 2007). The conflation of religious and political beliefs may be due to political and religious phenotypes representing the same latent trait or an interpretive cognition issue. Either way, demonstrating a shared genetic path between these variables and social ideology challenges the traditional social science treatment of religion and politics as separate theoretical realms, and this genetic path could explain either something like a latent trait of first principles or a cognitive conflation of concepts.

For example, in their discussion of "pathways to conservative identification," Ellis and Stimson (2011) posit that a sub-set of Americans self-report a conservative ideology while simultaneously supporting progressive government policies. One of their explanations is that some individuals may be conflating conservative religious theology with political conservatism. 
Our findings here support their argument: when individuals think about organizing society around moral values, they seem to be drawing upon a predisposition that also encompasses relying on religious belief in day-to-day decision making. This partially heritable religious orientation does not explain their economic policy preferences or their group attitudes, which may lead some of them to be “conflicted conservatives” (Ellis and Stimson 2011, 126).

Our research also supports the broader agenda that political ideology should not be treated as a unidimensional construct (e.g., Feldman and Johnston 2014). If we are to develop more nuanced models of political beliefs and their relationship to religion and other variables, it is necessary to examine not only the relationships among the aggregate measures of these constructs, but also their components. For example, our findings suggest that the pathways that explain shared variance between social ideology and religiosity also account for all of the variance shared between economic ideology and religiosity, but that these pathways account for a much greater proportion of the variation in social ideology than they do in economic ideology. This raises questions about what other traits may jointly underlie social and economic ideology and what traits explain variation in economic ideology but not social ideology.

Future research should consider the ways in which environmental factors can impact the effect of genes on social ideology, religiosity, and their covariation. This could occur through a gene by environment interaction, where the effects of genes differ across environments, or a gene by environment correlation, where genetic factors affect the likelihood that an individual will select into a particular environment. If the heritability of the overlapping political and religious attitudes can be thought of as the "ability to think or behave in accordance with one’s internal, biological motivations” (Bradshaw and Ellison 2008, 531), adding the reinforcement of an external behavior like church attendance may further strengthen or augment these beliefs. 
In sum, our results provide strong support for the notion that political and religious beliefs are in part the result of shared genetic and environmental factors. These genetic and environmental factors are also shared with endorsement of bedrock social principles regarding traditional moral values in society, suggesting that political and religious beliefs may in part stem from a common orientation towards change in society, which may be expressed in obedience to authority, social conformity, or some other notion of organizing group life (Ludeke, Johnson, and Bouchard 2013; Feldman 2003). Whether this underlying disposition exhibits political, religious, or both belief sets, then, is dependent on an individual's exposure to these environments. As mentioned earlier, a 1980s study in the USSR (McFarland 1998) determined that applying a religiosity battery to attitudes toward the Communist Party predicted the same relationships with social preferences as those identified when these measurements were used with American Christians. This provides more evidence for predispositions toward social order, which may inform religious and political beliefs that are dependent or “activated” by one’s environment. Findings along these lines could contribute to our understanding of what drives individual political attitudes, how genetic and environmental factors contribute to the formation and shifts in public opinion, and ultimately whether instantiated political-religious predispositions, much like personality, may drive political disagreement and conflict. 


\section{References}

Alford, J. R., Funk, C. L., \& Hibbing, J. R. (2005). Are Political Orientations Genetically Transmitted? American Political Science Review, 99(2), 153-167.

Alford, J. R., \& Hibbing, J. R. (2007). Personal, Interpersonal, and Political Temperaments. The ANNALS of the American Academy of Political and Social Science, 614(1), 196-212.

Altemeyer, R. 1981. Right-Wing Authoritarianism. Winnipeg, Canada: University of Manitoba Press.

Ansolabehere, Stephen, Jonathan Rodden, and James M. Snyder, Jr. (2008). The Strength of Issues: Using Multiple Measures to Gauge Preference Stability, Ideological Constraint, and Issue Voting. American Political Science Review, 102 (2), 215-232.

Boker, S., Neale, M., Maes, H., Wilde, M., Spiegel, M., Brick, T., et al. (2011). OpenMx: An Open Source Extended Structural Equation Modeling Framework. Psychometrika, 76(2), 306-317.

Bouchard Jr, T. J., McGue, M., Lykken, D., \& Tellegen, A. (1999). Intrinsic and extrinsic religiousness: genetic and environmental influences and personality correlates. Twin Research, 2(2), 88-98.

Bouchard, T. J. (2009). Authoritarianism, Religiousness, and Conservatism: Is 'Obedience to Authority’ the Explanation for Their Clustering, Universality and Evolution? In E. Voland, \& W. Schiefenhövel (Eds.), The Biological Evolution of Religious Mind and Behavior. (pp. 165-180). London: Springer.

Bradshaw, M., \& Ellison, C. G. (2008). Do Genetic Factors Influence Religious Life? Findings from a Behavior Genetic Analysis of Twin Siblings. Journal for the Scientific Study of Religion, 47(4), 529-544.

Carmines, E. G., Ensley, M. J., \& Wagner, M. W. (2012). Who Fits the Left-Right Divide? Partisan Polarization in the American Electorate. American Behavioral Scientist, 56(12), 1631-1653.

Clark, C. A., \& Worthington, E. L., Jr. (1990). Family variables affecting the transmission of religious values from parents to adolescents: A review. In B. K. Barber, \& B. C. Rollins (Eds.), Parent-adolescent relationships (pp. 167-191). Lanham, MD: University Press of America.

Converse, P. E. (1964). The Nature of Belief Systems in Mass Public. In D. Apter (Ed.), Ideology and Discontent (pp. 206-261). New York: Free Press.

Cornwall, M. (1989). The Determinants of Religious Behavior: A Theoretical Model and Empirical Test. Social Forces, 68(2), 572-592.

Coventry, W. L. and M. C. Keller (2005). "Estimating the Extent of Parameter Bias in the Classical Twin Design: A Comparison of Parameter Estimates From Extended TwinFamily and Classical Twin Designs." Twin Research and Human Genetics 8(03): 214- 
223.

Downs, A. (1957). The Causes and Effects of Rational Abstention. In An Economic Theory of Democracy. New York: Harper and Row (pp. 260-276).

Eaves, L. J., Hatemi, P. K., Prom-Womley, E. C., \& Murrelle, L. (2008). Social and Genetic Influences on Adolescent Religious Attitudes and Practices. Social Forces, 86(4), 16211646.

Ellis, C., \& Stimson, J. A. (2011). Pathways to Conservative Identification. In P. M. Sniderman, \& B. Highton (Eds.), Facing the Challenge of Democracy: Explorations in the Analysis of Public Opinion and Political Participation (pp. 120-148). Princeton, NJ: Princeton University Press.

Emerson, M. O., \& Smith, C. (2000). Divided by Faith: Evangelical Religion and the Problem of Race in America. Oxford: Oxford University Press.

Feldman, S. (2003), Enforcing Social Conformity: A Theory of Authoritarianism. Political Psychology, 24: 41-74.

Feldman, S., \& Johnston, C. (2014). Understanding the Determinants of Political Ideology: Implications of Structural Complexity. Political Psychology 35 (3): 337-358.

Fowler, J. H., \& Dawes, C. T. (2008). Two Genes Predict Voter Turnout. The Journal of Politics, 70(3), 579-594.

Francis, Leslie J. 2010. "Personality and Religious Orientation: Shifting Sands or Firm

Foundations?” Mental Health, Religion, and Culture 13(7/8): 793-803.

Friesen, A., \& Wagner, M. W. (2012). Beyond the "Three Bs": How American Christians Approach Faith and Politics. Politics and Religion, 5(2), 224-252.

Funk, C. L., Smith, K. B., Alford, J. R., Hibbing, M. V., Eaton, N. R., Krueger, R. F., Eaves, L. J. and Hibbing, J. R. (2013), Genetic and Environmental Transmission of Political Orientations. Political Psychology, 34: 805-819

Haidt, J. (2012). The Righteous Mind: Why Good People Are Divided by Politics and Religion. New York: Pantheon Books.

Hatemi, P., Medland, S., Morley, K., Heath, A., \& Martin, N. (2007). The Genetics of Voting: An Australian Twin Study. Behavior Genetics, 37(3), 435-448.

Hibbing, John R., Kevin B. Smith, and John R. Alford. (2014). Predisposed: Liberals, Conservatives, and the Biology of Political Differences. New York: Routledge.

Hills, Peter, Leslie J. Francis, Michael Argyle, and Chris J. Jackson. 2004. "Primary Personality Trait Correlates of Religious Practice and Orientation.” Personality and Individual Differences 36 (1): 61-73.

Hunter, J. D. (1991). Culture Wars: The Struggle to Define America. New York: Basic Books.

Jennings, M. K., \& Niemi, R. G. (1974). The Political Character of Adolescence: The Influence of Families and Schools. Princeton, NJ: Princeton University Press.

Jennings, M. K., Stoker, L., \& Bowers, J. (2009). Politics across Generations: Family Transmission Reexamined. The Journal of Politics, 71(3), 782-799.

Jost, J. T. (2006). The end of the end of ideology. American Psychologist, 61(7), 651-670. 
Jost, J. T., Glaser, J., Kruglanski, A. W., \& Sulloway, F. J. (2003). Political conservatism as motivated social cognition. Psychological Bulletin, 129(3), 339-375.

Kendler, K. S., Liu, X.-Q., Gardner, C. O., McCullough, M. E., Larson, D., \& Prescott, C. A. (2003). Dimensions of Religiosity and Their Relationship to Lifetime Psychiatric and Substance Use Disorders. American Journal of Psychiatry, 160(3), 496-503.

Kendler, Kenneth, and John Myers. (2009)"A developmental twin study of church attendance and alcohol and nicotine consumption: a model for analyzing the changing impact of genes and environment." American Journal of Psychiatry 166, (10): 1150-1155.

Kirk, K M; Maes, H H; Neale, M C; Heath, A C; Martin, N G; et al. June 1999. Twin research : the official journal of the International Society for Twin Studies 2.2 : 99-107.

Koenig, L. B., \& Bouchard, T. J. (2006). Genetic and Environmental Influences on the Traditional Moral Values Triad - Authoritarianism, Conservatism, and Religiousness - as Assessed by Quantitative Behavior Genetic Methods. In P. McNamara (Ed.), Where God and Science Meet: How Brain and Evolutionary Studies Alter Our Understanding of Religion (Vol. 1, pp. 31-60). Westport, CT: Praeger.

Layman, G. C. (2001). The Great Divide: Religious and Cultural Conflict in American Party Politics. New York: Columbia University Press.

Loehlin, J. C. 1996. The Cholesky approach: A cautionary note. Behavior Genetics 26 (1):65--69.

Ludeke, S., Johnson, W., \& Bouchard Jr, T. J. (2013). “Obedience to traditional authority:” A heritable factor underlying authoritarianism, conservatism and religiousness. Personality and Individual Differences, 55(4), 375-380.

McFarland, S. (1998). Communism as Religion. International Journal for the Psychology of Religion, 8(1), 33-48.

Medland, S. E., \& Hatemi, P. K. (2009). Political Science, Biometric Theory, and Twin Studies: A Methodological Introduction. Political Analysis, 17(2), 191-214.

Miller, G., \& Schofield, N. (2003). Activists and Partisan Realignment in the United States. American Political Science Review, 97(2), 245-260.

Mockabee, S. T., Wald, K. D., \& Leege, D. C. (2012). In Search of the Religious Left: Reexamining Religiosity. In J. Aldrich, \& K. McGraw (Eds.), Improving Public Opinion Surveys: Interdisciplinary Innovation and the American National Studies (pp. 278-298): Princeton, NJ: Princeton University Press.

Mondak, Jeffery J. 2010. Personality and the Foundations of Political Behavior. New York: Cambridge University Press.

Putnam, R. D., \& Campbell, D. E. (2012). American Grace: How Religion Divides and Unites Us: Simon and Schuster.

Ray, J.J. 1989. "The Scientific Study of Ideology is Too Often More Ideological Than Scientific.” Personality \& Individual Differences 10 (3): 331-336.

Robbins, Mandy, Leslie Francis, David McIlroy, Rachel Clarke, and Lowri Pritchard. 2010. "Three Religious Orientations and Five Personality Factors: An Exploratory Study Among Adults in England.” Mental Health, Religion \& Culture 13 (7-8): 771-775. 
Saroglou, Vassilis. 2002. "Religion and the Five Factors of Personality: A Meta-analytic

Review.” Personality and Individual Differences 32: 15-25.

Saucier, G., and L.R. Goldberg. 1998. "What is Beyond the Big Five?” Journal of Personality 66:495-524.

Settle, J. E., Dawes, C. T., Christakis, N. A., \& Fowler, J. H. (2010). Friendships Moderate an Association between a Dopamine Gene Variant and Political Ideology. The Journal of Politics, 72(4), 1189-1198.

Smidt, C. E., den Dulk, K. R., Froehle, B. T., Penning, J. M., Monsma, S. V., \& Koopman, D. L. (2010). The Disappearing God Gap? Religion in the 2008 Presidential Election. Oxford, UK: Oxford University Press.

Smidt, C. E., Kellstedt, L. A., \& Guth, J. L. (2009). The Role of Religion in American Politics: Explanatory Theories and Associated Analytical and Measurement Issues. In C. E. Smidt, L. A. Kellstedt, \& J. L. Guth (Eds.), The Oxford Handbook of Religion and American Politics (pp. 3-42). Oxford: Oxford University Press.

Smith, K., Alford, J. R., Hatemi, P. K., Eaves, L. J., Funk, C., \& Hibbing, J. R. (2012). Biology, Ideology, and Epistemology: How Do We Know Political Attitudes Are Inherited and Why Should We Care? American Journal of Political Science, 56(1), 17-33.

Smith, K. B., Oxley, D. R., Hibbing, M. V., Alford, J. R., \& Hibbing, J. R. (2011a). Disgust Sensitivity and the Neurophysiology of Left-Right Political Orientations. PLoS ONE, 6(10), 1-9.

Smith, K. B., Oxley, D. R., Hibbing, M. V., Alford, J. R., \& Hibbing, J. R. (2011b). Linking Genetics and Political Attitudes: Reconceptualizing Political Ideology. Political Psychology, 32(3), 369-397.

Snow, D. A., Rochford, E. B., Jr., Worden, S. K., \& Benford, R. D. (1986). Frame Alignment Processes, Micromobilization, and Movement Participation. American Sociological Review, 51(4), 464-481.

Tedin, K. L. (1974). The Influence of Parents on the Political Attitudes of Adolescents. The American Political Science Review, 68(4), 1579-1592.

Thomas, L. E. (1971). Political Attitude Congruence between Politically Active Parents and College-Age Children: An Inquiry into Family Political Socialization. Journal of Marriage and Family, 33(2), 375-386.

Truett, K. R., Eaves, L. J., Meyer, J. M., Heath, A. C., \& Martin, N. G. (1992). Religion and education as mediators of attitudes: A multivariate analysis. Behavior Genetics, 22(1), 43-62.

Vance, T., Maes, H. H., \& Kendler, K. S. (2010). Genetic and Environmental Influences on Multiple Dimensions of Religiosity. The Journal of Nervous and Mental Disease, 198(10), 755-761.

Verhulst, B., Eaves, L. J., \& Hatemi, P. K. (2012). Correlation not Causation: The Relationship between Personality Traits and Political Ideologies. American Journal of Political Science, 56(1), 34-51.

Wald, K. D., \& Calhoun-Brown, A. (2007). Religion and American Politics in the United States 
(5th ed.). Lanham, MD: Rowman and Littlefield.

Wilson, G. D., \& Patterson, J. R. (1968). A New Measure of Conservatism. British Journal of Social and Clinical Psychology, 7(4), 264-269.

Wuthnow, R. (1988). The Restructuring of American religions: Society and Faith Since World War II. Princeton, NJ: Princeton University Press.

Zuckerman, A. S., Dasović, J., \& Fitzgerald, J. (2007). Partisan Families: The Social Logic of Bounded Partisanship in Germany and Britain. Cambridge: Cambridge University Press. 
Table 1: Within-twin correlations of religious, Society Works Best, and political variables

\begin{tabular}{|c|c|c|c|c|c|c|c|c|c|}
\hline & $\begin{array}{c}\text { Religiosity } \\
\text { (Importance) }\end{array}$ & $\begin{array}{c}\text { Religiosity } \\
\text { (Attendance) }\end{array}$ & $\begin{array}{l}\text { SWB } \\
\text { (Full) }\end{array}$ & $\begin{array}{c}\text { SWB } \\
\text { (Values) }\end{array}$ & $\begin{array}{c}\text { SWB } \\
\text { (Group) }\end{array}$ & $\begin{array}{c}\text { SWB } \\
\text { (Leader) }\end{array}$ & $\begin{array}{l}\text { Ideology } \\
\text { (Full) }\end{array}$ & $\begin{array}{r}\text { Ideology } \\
\text { (Social) }\end{array}$ & $\begin{array}{c}\text { Ideology } \\
\text { (Economic) }\end{array}$ \\
\hline $\begin{array}{c}\text { Religiosity } \\
\text { (Importance) }\end{array}$ & 1 & & & & & & & & \\
\hline $\begin{array}{l}\text { Religiosity } \\
\text { (Attendance) }\end{array}$ & 0.58 & 1 & & & & & & & \\
\hline $\begin{array}{l}\text { SWB } \\
\text { (Full) }\end{array}$ & 0.21 & 0.20 & 1 & & & & & & \\
\hline $\begin{array}{c}\text { SWB } \\
\text { (Values) }\end{array}$ & 0.32 & 0.30 & 0.78 & 1 & & & & & \\
\hline $\begin{array}{l}\text { SWB } \\
\text { (Group) }\end{array}$ & -0.01 & -0.02 & 0.75 & 0.25 & 1 & & & & \\
\hline $\begin{array}{c}\text { SWB } \\
\text { (Leader) }\end{array}$ & 0.12 & 0.13 & 0.48 & 0.27 & 0.13 & 1 & & & \\
\hline $\begin{array}{l}\text { Ideology } \\
\text { (Full) }\end{array}$ & 0.44 & 0.40 & 0.59 & 0.57 & 0.34 & 0.26 & 1 & & \\
\hline $\begin{array}{l}\text { Ideology } \\
\text { (Social) }\end{array}$ & 0.53 & 0.51 & 0.52 & 0.56 & 0.22 & 0.27 & 0.92 & 1 & \\
\hline $\begin{array}{c}\text { Ideology } \\
\text { (Economic) }\end{array}$ & 0.16 & 0.08 & 0.35 & 0.29 & 0.27 & 0.12 & 0.61 & 0.40 & 1 \\
\hline
\end{tabular}


Table 2: Cross-twin correlations of religious, Society Works Best, and political variables

\begin{tabular}{|c|c|c|c|c|c|c|c|c|c|}
\hline & $\begin{array}{c}\text { Religiosity } \\
\text { (Importance) }\end{array}$ & $\begin{array}{c}\text { Religiosity } \\
\text { (Attendance) }\end{array}$ & $\begin{array}{l}\text { SWB } \\
\text { (Full) }\end{array}$ & $\begin{array}{c}\text { SWB } \\
\text { (Values) }\end{array}$ & $\begin{array}{c}\text { SWB } \\
\text { (Group) }\end{array}$ & $\begin{array}{c}\text { SWB } \\
\text { (Leader) }\end{array}$ & $\begin{array}{l}\text { Ideology } \\
\text { (Full) }\end{array}$ & $\begin{array}{c}\text { Ideology } \\
\text { (Social) }\end{array}$ & $\begin{array}{c}\text { Ideology } \\
\text { (Economic) }\end{array}$ \\
\hline $\begin{array}{l}\text { Religiosity } \\
\text { (Importance) }\end{array}$ & 0.48 & & & & & & & & \\
\hline $\begin{array}{l}\text { Religiosity } \\
\text { (Attendance) }\end{array}$ & 0.35 & 0.51 & & & & & & & \\
\hline $\begin{array}{l}\text { SWB } \\
\text { (Full) }\end{array}$ & 0.13 & 0.18 & 0.39 & & & & & & \\
\hline $\begin{array}{c}\text { SWB } \\
\text { (Values) }\end{array}$ & 0.20 & 0.25 & 0.33 & 0.38 & & & & & \\
\hline $\begin{array}{l}\text { SWB } \\
\text { (Group) }\end{array}$ & 0.02 & 0.04 & 0.30 & 0.14 & 0.37 & & & & \\
\hline $\begin{array}{c}\text { SWB } \\
\text { (Leader) }\end{array}$ & 0.03 & 0.05 & 0.14 & 0.11 & 0.05 & 0.19 & & & \\
\hline $\begin{array}{l}\text { Ideology } \\
\text { (Full) }\end{array}$ & 0.31 & 0.27 & 0.42 & 0.35 & 0.30 & 0.18 & 0.64 & & \\
\hline $\begin{array}{l}\text { Ideology } \\
\text { (Social) }\end{array}$ & 0.35 & 0.33 & 0.38 & 0.36 & 0.22 & 0.19 & 0.60 & 0.62 & \\
\hline $\begin{array}{c}\begin{array}{c}\text { Ideology } \\
\text { (Economic) }\end{array} \\
\end{array}$ & 0.16 & 0.06 & 0.23 & 0.14 & 0.21 & 0.10 & 0.43 & 0.36 & 0.39 \\
\hline \multicolumn{10}{|c|}{ Note: Bold pair-wise correlations are significant at $\mathrm{p}<.05$} \\
\hline \multicolumn{10}{|l|}{ DZ Twins } \\
\hline & $\begin{array}{c}\text { Religiosity } \\
\text { (Importance) }\end{array}$ & $\begin{array}{c}\text { Religiosity } \\
\text { (Attendance) }\end{array}$ & $\begin{array}{l}\text { SWB } \\
\text { (Full) }\end{array}$ & $\begin{array}{c}\text { SWB } \\
\text { (Values) }\end{array}$ & $\begin{array}{c}\text { SWB } \\
\text { (Group) }\end{array}$ & $\begin{array}{c}\text { SWB } \\
\text { (Leader) }\end{array}$ & $\begin{array}{l}\text { Ideology } \\
\text { (Full) }\end{array}$ & $\begin{array}{c}\text { Ideology } \\
\text { (Social) }\end{array}$ & $\begin{array}{c}\text { Ideology } \\
\text { (Economic) }\end{array}$ \\
\hline $\begin{array}{c}\text { Religiosity } \\
\text { (Importance) }\end{array}$ & 0.27 & & & & & & & & \\
\hline $\begin{array}{l}\text { Religiosity } \\
\text { (Attendance) }\end{array}$ & 0.30 & 0.41 & & & & & & & \\
\hline $\begin{array}{l}\text { SWB } \\
\text { (Full) }\end{array}$ & 0.08 & 0.13 & 0.15 & & & & & & \\
\hline $\begin{array}{c}\text { SWB } \\
\text { (Values) }\end{array}$ & 0.11 & 0.20 & 0.15 & 0.19 & & & & & \\
\hline $\begin{array}{l}\text { SWB } \\
\text { (Group) }\end{array}$ & -0.03 & -0.05 & 0.06 & 0.04 & 0.07 & & & & \\
\hline $\begin{array}{c}\text { SWB } \\
\text { (Leader) }\end{array}$ & 0.10 & 0.11 & 0.08 & 0.07 & 0.00 & 0.14 & & & \\
\hline $\begin{array}{l}\text { Ideology } \\
\text { (Full) }\end{array}$ & 0.19 & 0.21 & 0.14 & 0.15 & 0.07 & 0.04 & 0.37 & & \\
\hline $\begin{array}{l}\text { Ideology } \\
\text { (Social) }\end{array}$ & 0.27 & 0.31 & 0.13 & 0.18 & 0.04 & 0.02 & 0.36 & 0.39 & \\
\hline $\begin{array}{l}\text { Ideology } \\
\text { (Economic) }\end{array}$ & 0.06 & 0.01 & 0.05 & 0.03 & 0.05 & 0.06 & 0.20 & 0.15 & 0.21 \\
\hline
\end{tabular}


Table 3: Descriptive Statistics

\begin{tabular}{|c|c|c|c|c|c|c|}
\hline \multicolumn{2}{|l|}{ Variable } & & & & & \\
\hline Religiosity (Importance) & type & Mean & Standard Deviation & Minimum & Maximum & $\mathrm{N}$ \\
\hline & All & 0.64 & 0.33 & 0 & 1 & 1322 \\
\hline & $\mathrm{MZ}$ & 0.64 & 0.33 & 0 & 1 & 775 \\
\hline & $\mathrm{DZ}$ & 0.64 & 0.33 & 0 & 1 & 547 \\
\hline Religiosity (Attendance) & All & 0.52 & 0.29 & 0 & 1 & 1322 \\
\hline & $\mathrm{MZ}$ & 0.52 & 0.29 & 0 & 1 & 775 \\
\hline & $\mathrm{DZ}$ & 0.52 & 0.29 & 0 & 1 & 547 \\
\hline SWB (Full) & All & -0.10 & 0.36 & -1 & 1 & 1324 \\
\hline & $\mathrm{MZ}$ & -0.10 & 0.37 & -1 & 0.83 & 774 \\
\hline & $\mathrm{DZ}$ & -0.10 & 0.35 & -1 & 1 & 550 \\
\hline SWB (Values) & All & -0.31 & 0.63 & -1 & 1 & 1326 \\
\hline & $\mathrm{MZ}$ & -0.31 & 0.62 & -1 & 1 & 775 \\
\hline & $\mathrm{DZ}$ & -0.30 & 0.63 & -1 & 1 & 551 \\
\hline SWB (Group) & All & 0.24 & 0.41 & -1 & 1 & 1331 \\
\hline & MZ & 0.24 & 0.42 & -1 & 1 & 777 \\
\hline & $\mathrm{DZ}$ & 0.24 & 0.41 & -1 & 1 & 554 \\
\hline SWB (Leader) & All & -0.71 & 0.54 & -1 & 1 & 1336 \\
\hline & $\mathrm{MZ}$ & -0.71 & 0.55 & -1 & 1 & 782 \\
\hline & $\mathrm{DZ}$ & -0.73 & 0.53 & -1 & 1 & 554 \\
\hline Ideology (Full) & All & 0.54 & 0.14 & 0.10 & 0.91 & 1285 \\
\hline & $\mathrm{MZ}$ & 0.54 & 0.14 & 0.10 & 0.91 & 750 \\
\hline & $\mathrm{DZ}$ & 0.54 & 0.14 & 0.18 & 0.91 & 535 \\
\hline Ideology (Social) & All & 0.52 & 0.19 & 0.06 & 0.96 & 1313 \\
\hline & $\mathrm{MZ}$ & 0.52 & 0.19 & 0.06 & 0.96 & 769 \\
\hline & $\mathrm{DZ}$ & 0.52 & 0.19 & 0.06 & 0.96 & 544 \\
\hline Ideology (Economic) & All & 0.72 & 0.19 & 0 & 1 & 1331 \\
\hline & $\mathrm{MZ}$ & 0.71 & 0.19 & 0 & 1 & 781 \\
\hline & $\mathrm{DZ}$ & 0.72 & 0.19 & 0 & 1 & 550 \\
\hline
\end{tabular}


Figure 1:

Conceptual models

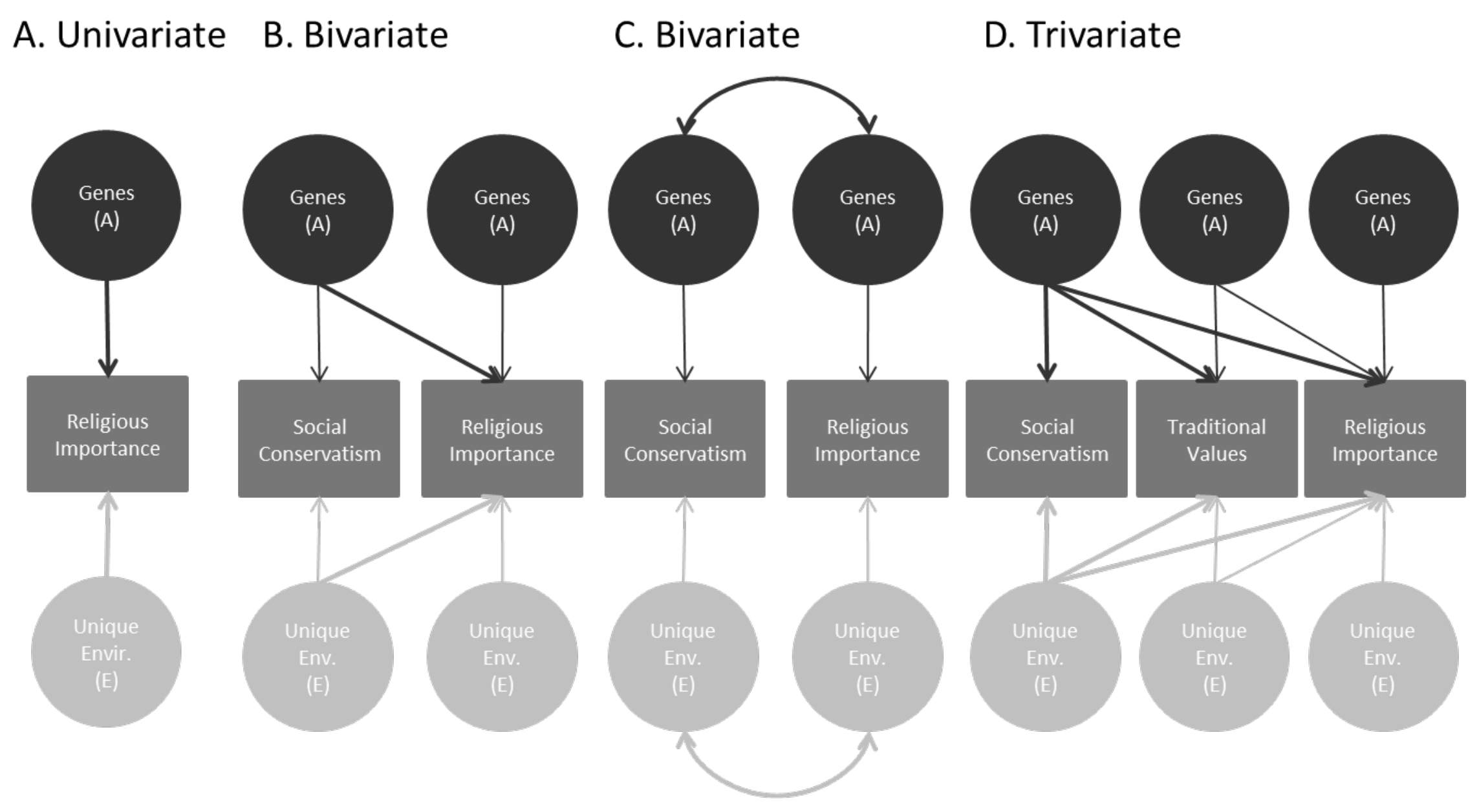


Figure 2: Univariate Results

Each Variable Has Genetic and Unique Environmental Components

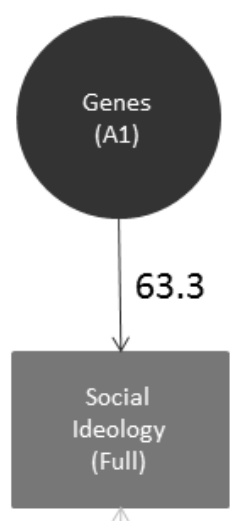

36.7

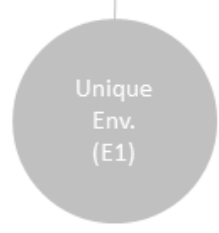

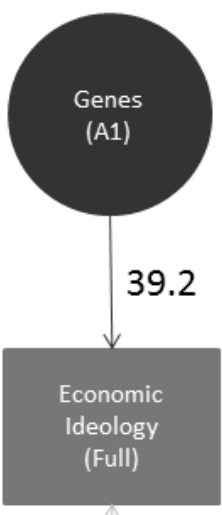

60.8

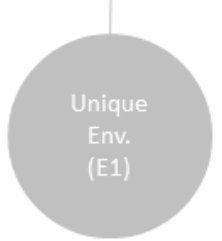

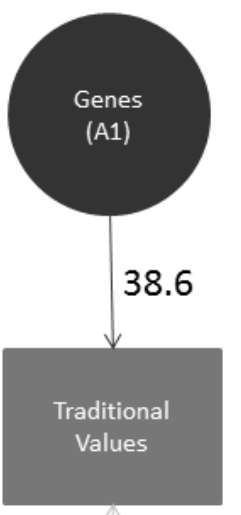

61.4

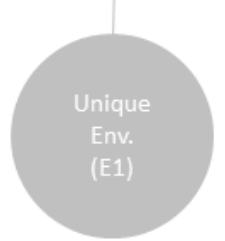

Genes

(A1)

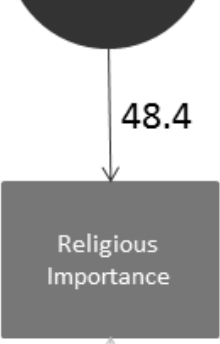

51.6

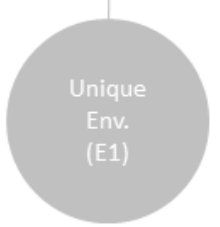

Paths indicate the percent of the variance explained by each component.

Solid lines are significant at $p<0.05$; dashed lines are not statistically significant. Full model estimates are available in the appendix (Table 1). 


\section{Figure 3: Bivariate Results}

Religious Importance Shares Genetic \& Environmental Variance with Other Traits

\section{A. Correlation with Religious Importance}
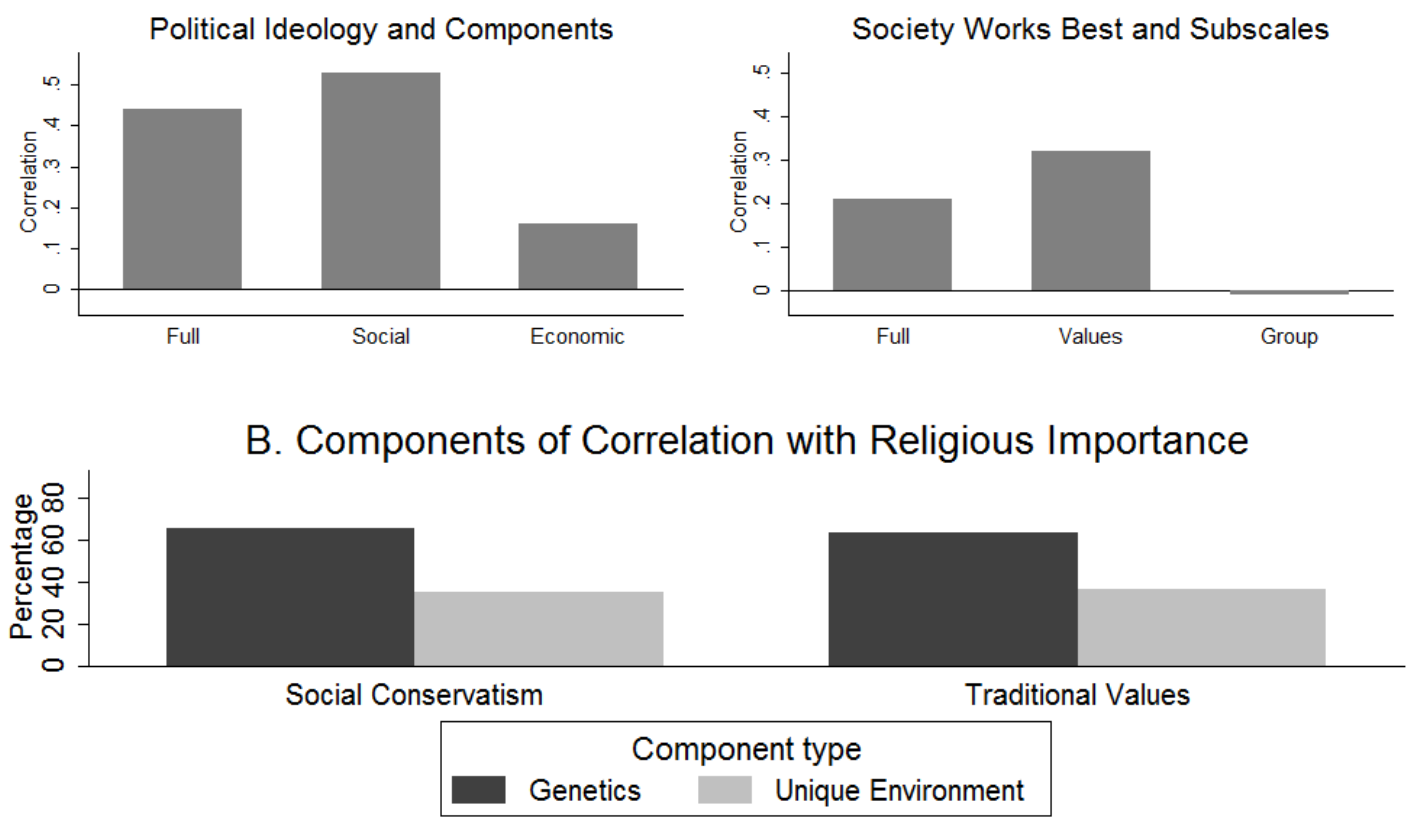
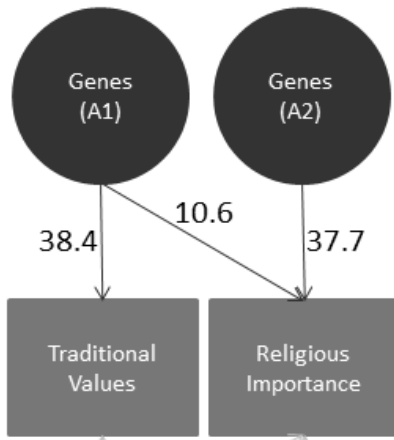

37.7
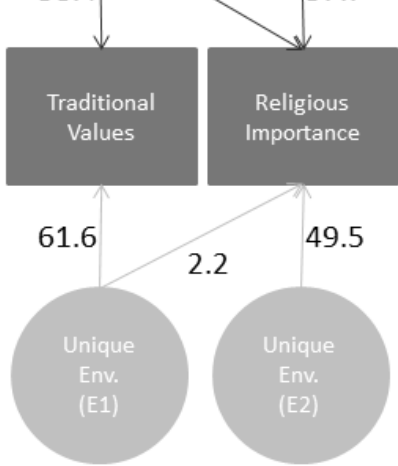

Paths indicate the percent of the variance explained by each component. Solid lines are significant at $p<0.05$; dashed lines are not statistically significant. Full model estimates are available in the appendix (Table 2). 
Figure 4: Trivariate Results

One Common Genetic Factor Links Religious Importance to Other Traits
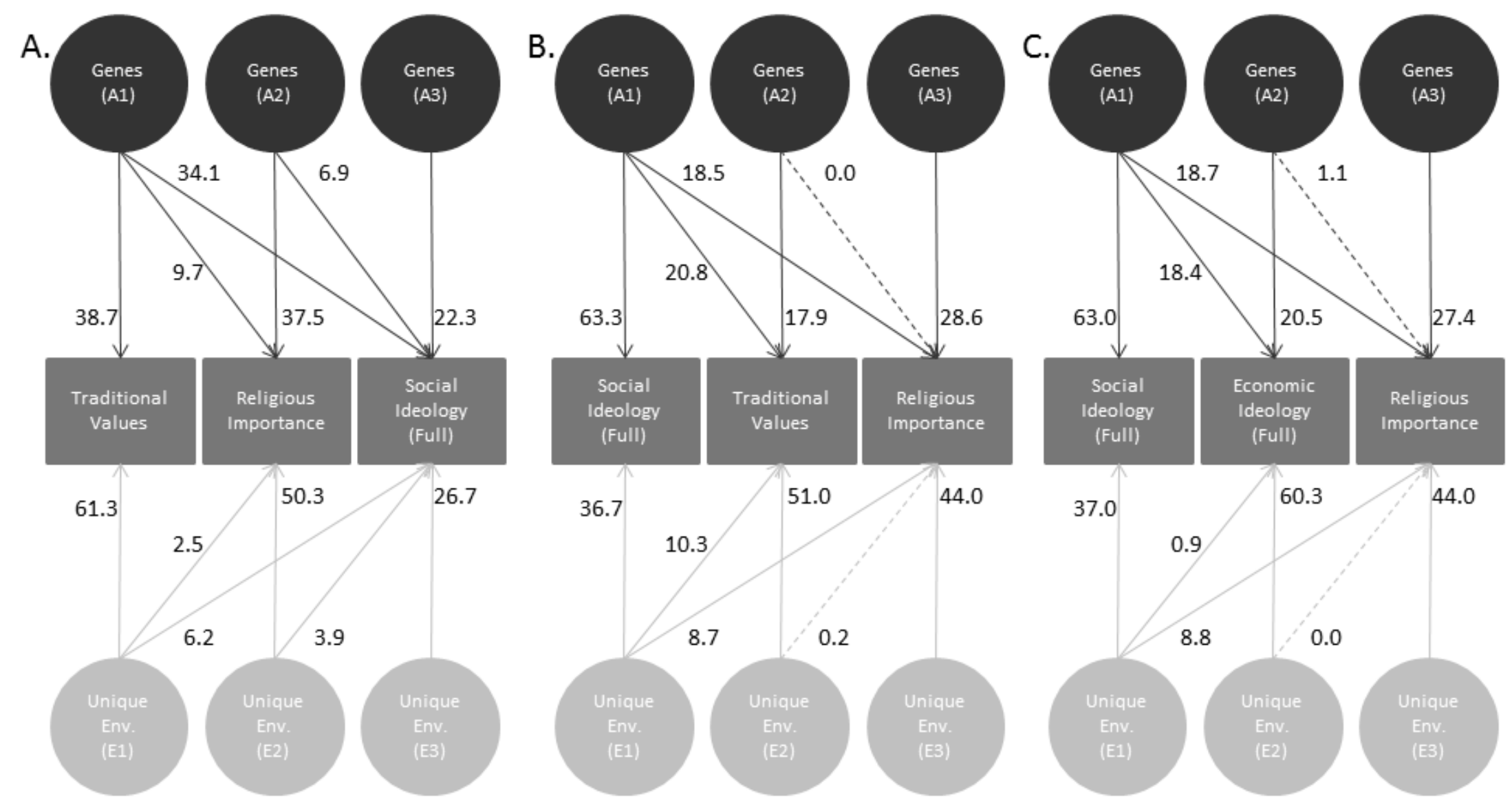

Paths indicate the percent of the variance explained by each component.

Solid lines are significant at $p<0.05$; dashed lines are not statistically significant.

Fill mndel ectimatec are arilahle in the annendix (Tدhlo 2 ) 


\section{Appendix}

\section{Religiosity variables}

[Attendance]

How often do you attend religious services?

- More than once a week

- Once a week

- Once or twice a month

- A few times a year

- Rarely

- Never

[Importance]

Whether or not you attend services, how much do you consider religion to be an important part of your life? Would you say your religious beliefs provide...

- A great deal of guidance in your day-to-day living

- Quite a bit of guidance in your day-to-day living

- Some guidance in your day-to-day living

- Are not an important part of your life

\section{Society Works Best subscales}

\section{Group}

1 - Society works best when...

people realize the world is dangerous

OR people assume that all those in far away places are kindly

4 - Society works best when...

we take care of our own people first

OR we realize people everywhere deserve our help

7 - Society works best when...

people take primary responsibility for their own welfare

OR people join together to help others

9 - Society works best when...

people recognize the unavoidable flaws of human nature

OR people recognize that humans can be changed in positive ways

10 - Society works best when...

every member contributes the same amount

OR more fortunate members contribute more in order to help others

12 - Society works best when...

those who break the rules are punished

OR those who break the rules are forgiven 
Values

3 - Society works best when... established ideas are favored

OR new ideas are favored

5 - Society works best when...

leaders compromise with their opponents in order to get things done OR leaders adhere to their principles no matter what

6 - Society works best when...

people live according to traditional values

OR people adjust their values to fit changing circumstances

11 - Society works best when...

behavioral expectations are based on an eternal code

OR behavioral expectations are allowed to evolve over the decades

\section{Leader}

2 - Society works best when...

leaders are obeyed

OR leaders are questioned

8 - Society works best when...

it speaks with one voice

OR it speaks with many voices

\section{Wilson Patterson subscales}

Social ideology

1 - School prayer

4 - Pornography

6 - Women's equality

7 - Death penalty

8 - Premarital sex

9 - Gay marriage

10 - Abortion rights

11 - Evolution

13 - Biblical truth

16 - Protect gun rights

25 - Stem cell research

26 - Abstinence-only sex education

Economic ideology

15 - Increase welfare spending

21 - Small government

24 - Lower taxes 